Proc. Estonian Acad. Sci. Biol. Ecol., 2001, 50, 4, 269-278

\title{
WATER QUALITY IN THE PIRITA RIVER, A RAW WATER SOURCE FOR TALLINN
}

\author{
Rein RANNAMÄE ${ }^{\mathrm{a}}$ and Ingeborg VELDRE ${ }^{\mathrm{b}}$ \\ ${ }^{\text {a }}$ Health Protection Service of Harjumaa and Tallinn, Narva mnt. 48, 10150 Tallinn, Estonia \\ $\mathrm{b}$ Institute of Experimental and Clinical Medicine, Hiiu 42, 11619 Tallinn, Estonia \\ Received 2 March 2001, in revised form 11 June 2001
}

\begin{abstract}
The quality of the water of the Pirita River was evaluated on the ground of organoleptical, chemical, and microbiological analyses. Background values of some water quality indicators in the Pirita River were often higher than in the Pirita-Ülemiste Canal. The oxygen regime in the river was favourable ensuring the required conditions for self-purification. The $\mathrm{BOD}_{7} / \mathrm{PC}$ ratio of the river water was low, which shows that natural biochemically stable substances dominate in the water. Phenols in the river water were of vegetable origin. The concentrations of oil products and detergents in the river water were at the level of the sensitivity of the relevant determination methods. From the point of view of environmental health the raw water of the Pirita River is safe to be directed into the distribution system of the Tallinn Water Treatment Plant.
\end{abstract}

Key words: river water, raw water, water quality, drinking water.

The water supply of the city of Tallinn is based on surface and ground water with $91 \%$ of the water consumption satisfied by surface water. The average water consumption of an inhabitant of Tallinn was $120.3 \mathrm{~L} /$ day in 1999 and $133 \mathrm{~L} /$ day in 2000. The system of surface water supply of Tallinn includes the drainage basins of the upper reaches of the Pirita, Jägala, Soodla, and Pärnu rivers, the reservoirs on these rivers (Soodla, Paunküla, and Vaskjala), and also lakes Ülemiste and Raku (Fig. 1). The drainage basin of Pirita-Ülemiste covers about a third of the territory of Harju County, which raises additional requirements to the environmental protection of that region. The surface water is collected in Vaskjala Reservoir behind the dam of the Vaskjala hydroelectric power station. Further, the water moves through the Pirita-Ülemiste Canal to the treatment plant, situated on the north shore of Lake Ülemiste. The quality of the treated water must satisfy the general requirements of the Estonian drinking water standard (Eesti Standard, 1995). The higher the quality of the raw water entering 


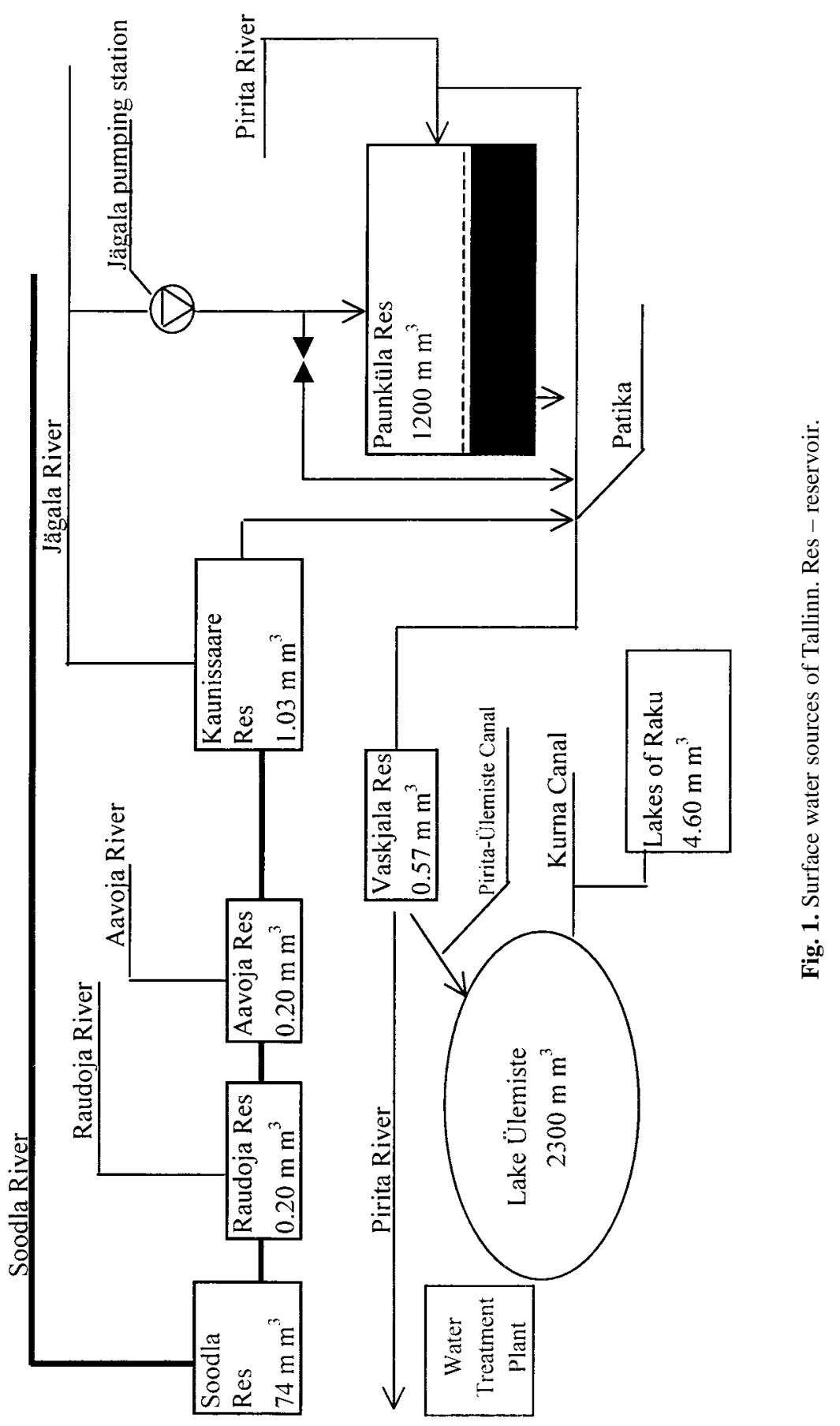


the system, the higher is the quality of treated water and the lower are the costs of the treatment process to achieve a high quality of water. In addition to making the treatment process more expensive, low quality of raw water may cause problems in supplying the city with high quality water.

The quality of drinking water, as well as the surface water sources of Tallinn, is investigated periodically. However, the quality of water in the Pirita River basin has not been thoroughly studied after 1994. Since then the amounts of agricultural waste products have diminished, but technical services and working regimes of sewage purification systems have deteriorated and therefore the effectiveness of the systems has decreased.

The motivations for studying the quality of raw water in the Pirita River were the following:

- The low quality of raw water demands additional quantities of coagulants for the treatment process;

- The condition of water pipes is deteriorating and the velocity of water flow is decreasing. Water consumption has fallen and the water stays in the pipes for a long time;

- The increasing doses of coagulants activate corrosion in the water pipes when two-valent iron is oxidizing into three-valent iron, which is then deposited in sediments. The colour and turbidity of water are rising;

- Complaints of consumers are becoming more frequent.

In our study we were interested in the quality of the water of the Pirita River, particularly as concerns its colour, concentration of nitrogen compounds, and content of organic substances. These indicators make it possible to evaluate the anthropogenic pollution with sewage as well as the influence of natural processes on the quality of river water. The aim of our study was to evaluate the quality of raw water and, if necessary, suggest improvements.

\section{MATERIAL AND METHODS}

The study was carried out from May to September 1999 and in April 2000. In 1999 water samples were taken five times (once each month) and in April 2000, three times. The water samples were taken from Paunküla Reservoir (site I) to Vaskjala Reservoir (site VII), and from the Pirita-Ülemiste Canal (site VIII) (Fig. 2). Although analysis of water from sites II-VI revealed some changes in the river water quality, it is most important to evaluate its quality when it enters Lake Ülemiste. Comparison of sites I, VII, and VIII makes it possible to estimate changes in the water quality from the background data in the Pirita River to Lake Ülemiste.

The necessary amount of water for analyses was taken from the Pirita River and the Pirita-Ülemiste Canal in the current at a depth of $20-30 \mathrm{~cm}$ from the water surface by a skilled person. The water samples were analysed at a scheduled time, after which they were not preserved. 


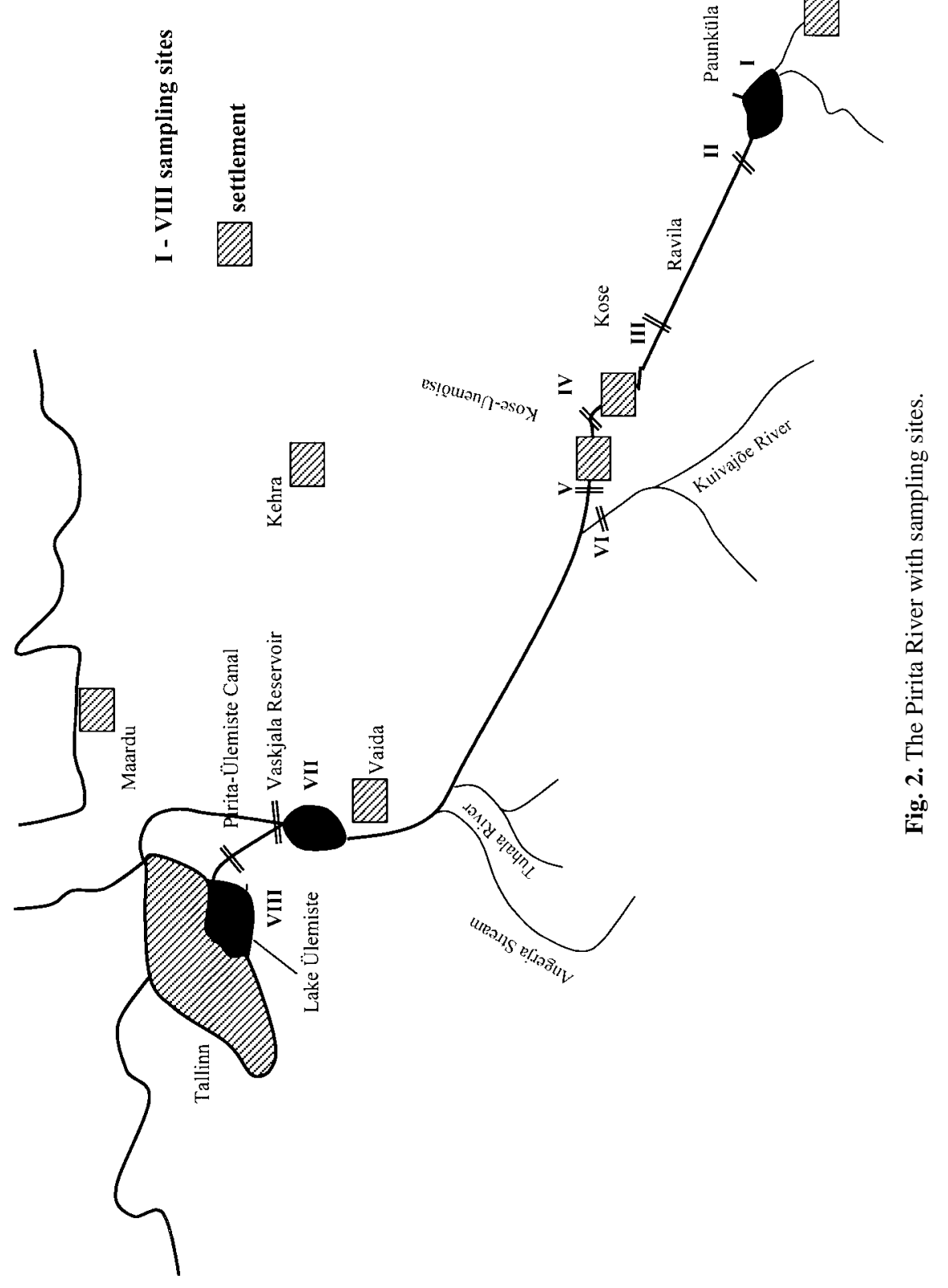


In all water samples organoleptical, chemical, and microbiological parameters were studied. All the tests were chosen according to the Estonian drinking water standard (Eesti Standard, 1995). Colour, odour, and transparency were tested organoleptically. Chemical analyses were used to assess the $\mathrm{pH}$ value, soluble oxygen, permanganate consumption (in $\mathrm{mg} \mathrm{O}_{2} \mathrm{~L}^{-1} \mathrm{KMnO}_{4}$ ), biochemical oxygen demand $\left(\mathrm{BOD}_{7}\right)$, ammonia, nitrites, and nitrates. Microbiological tests were applied to detect coliform bacteria, thermotolerant coliform bacteria, and heterotrophic bacteria.

All the organoleptical and chemical analyses were carried out in the Central Chemical Laboratory and the microbiological analyses in the Central Microbiological Laboratory of the Health Protection Inspectorate in accordance with the analytical methods of ISO (International Organisation for Standardisation) standards accepted in Estonia.

Concentrations of oil products and phenols were analysed in the Estonian Central Laboratory of Environmental Investigations. Oil products were extracted from water with $n$-pentane and analysed gas chromatographically. Their concentration was determined on a Japanese spectrofluorometer RF-540 Shimadzu at a synchronized scanning regime.

The sum of oil products includes non- or little polarized hydrocarbons aliphatic, acyclic, and aromatic hydrocarbons, which are soluble in $n$-pentane and represent the main part of oil products. High performance liquid chromatography was applied for the determination of one-basic (volatile) and two-basic (nonvolatile) phenols in water.

The presence and quantity of detergents were determined by the extractioncolorimetric method with methylene blue. The sensitivity of the method was $0.05-0.1 \mathrm{mg} \mathrm{L}^{-1}$.

\section{RESULTS AND DISCUSSION}

The chlorination process, usually applied to disinfect drinking water, is accompanied by formation of trihalomethanes (THMs), mainly chloroform. THMs are dangerous to humans: IARC qualifies chloroform as a possible carcinogen for humans of group 2B (WHO, 1987). THMs are formed by chemical interaction between chlorine and natural organic materials in water (Vogt \& Regli, 1981). The precursors of chloroform remain largely unknown, but humic and fulvic acids are considered to be major precursors (Bedding et al., 1983).

Analysis of chloroform was not included in our study because concentrations of THMs in Lake Ülemiste have been formerly investigated (Tammepuu, 1992). The chloroform content in the water of Lake Ülemiste was found to be far below the permissible level, the samples of chlorinated water containing from 11.8 to $97.8 \mu \mathrm{g} \mathrm{L} \mathrm{L}^{-1}$ of chloroform. Studying different stages of water treatment processes Tammepuu found that the concentration of chloroform depends on the character of raw water, treatment technology, and methods of chlorination. The doses of 
chlorine as well as the time of contact are important. The chloroform concentrations in drinking water varied in different seasons. The highest concentrations were found in summer - about 2-3 times higher than the permissible level of THMs at that time, which was $30 \mu \mathrm{g} \mathrm{L}{ }^{-1}$ till 1993. In 1993 WHO recommended $200 \mu \mathrm{gL}^{-1}$ as permissible level for chloroform.

Since 1997, when the Tallinn Water Treatment Plant introduced ozonation, the consumption of chlorine has fallen to $20 \%$ from the former level and is presently only $1.5 \mathrm{~g} \mathrm{~m}^{-3}$.

The transparency of river water was in all samples above $30 \mathrm{~cm}$. The background colour of water at site I was due to the presence of organic compounds extremely high, reaching $270^{\circ}$. During our study it was still increasing. The intensive colour of river water is caused by high concentrations of humic substances originating from the drainage basin. Soluble organic substances enter the river water mainly from the marshland and forests at the lower reaches of the river.

Most organic substances, formed from remains of plants on the surface of water, are washed into deeper layers of soil or into water during autumn rains. The remainder stays in the frozen soil and is washed into the river during the spring high water after the melting of snow and frozen soil.

The $\mathrm{pH}$ value of the river water at Paunküla and Vaskjala reservoirs and in the Pirita-Ülemiste Canal did not exceed the limits set by the drinking water standard as 6.5-8.5 (Eesti Standard, 1995) throughout our study.

Table 1 presents average values of the most important indicators of the water quality of the Pirita River in summer and during the spring high water. The

Table 1. The quality of the Pirita River water (average data) at sites I, VII, and VIII

\begin{tabular}{|c|c|c|c|c|c|c|}
\hline \multirow[t]{2}{*}{ Parameter } & \multicolumn{2}{|c|}{$\begin{array}{c}\text { Site I } \\
\text { (Pirita River at } \\
\text { Paunküla Reservoir) }\end{array}$} & \multicolumn{2}{|c|}{$\begin{array}{c}\text { Site VII } \\
\text { (Pirita River at } \\
\text { Vaskjala Reservoir) }\end{array}$} & \multicolumn{2}{|c|}{$\begin{array}{c}\text { Site VIII } \\
\text { (Pirita-Ülemiste } \\
\text { Canal) }\end{array}$} \\
\hline & Summer $^{\mathrm{a}}$ & Spring $^{\mathrm{b}}$ & Summer $^{\mathrm{a}}$ & Spring $^{\mathrm{b}}$ & Summer $^{\mathrm{a}}$ & Spring $^{\mathrm{b}}$ \\
\hline $\mathrm{pH}$ & 7.73 & 7.53 & 7.92 & 7.92 & 7.98 & 7.79 \\
\hline Ammonia, $\mathrm{mg} \mathrm{L}^{-1}$ & 0.59 & 0.86 & 0.44 & 0.65 & 0.40 & 0.84 \\
\hline Nitrites, $\mathrm{mg} \mathrm{L}^{-1}$ & 0.043 & 0.019 & 0.026 & 0.021 & 0.024 & 0.036 \\
\hline Nitrates, $\mathrm{mg} \mathrm{L}^{-1}$ & 1.4 & 4.46 & 2.9 & 9.2 & 1.6 & 9.5 \\
\hline $\begin{array}{l}\text { Permanganate consumption, } \\
\mathrm{mg} \mathrm{O}_{2} \mathrm{~L}^{-1} \mathrm{KMnO}_{4}\end{array}$ & 11.2 & 24.5 & 10.7 & 16.3 & 12.8 & 16.0 \\
\hline $\mathrm{BOD}_{7}, \mathrm{mg} \mathrm{O}_{2} \mathrm{~L}^{-1}$ & 2.1 & 1.9 & 2.1 & 1.4 & 3.3 & 1.6 \\
\hline Soluble oxygen, $\mathrm{mg} \mathrm{O}_{2} \mathrm{~L}^{-1}$ & 8.2 & 8.4 & 9.4 & 11.2 & 7.9 & 10.5 \\
\hline $\mathrm{BOD}_{7} / \mathrm{PC}$ & 0.19 & 0.08 & 0.20 & 0.09 & 0.26 & 0.1 \\
\hline
\end{tabular}


content of organic substances in the water of the Pirita River was evaluated on the basis of permanganate consumption $(\mathrm{PC}), \mathrm{BOD}_{7}$, and the quantity of soluble oxygen in water. As the characteristics of river water may vary in different hydrological periods it was necessary to compare the results of water analyses during the summer dry period and during the spring high water. In the samples of all three sites PC and the content of nitrates and ammonia were higher in spring than in summer; $\mathrm{BOD}_{7}$, on the contrary, showed in summer an increasing tendency in comparison with the spring period.

During our investigation the concentrations of ammonia, nitrites, and nitrates in the Pirita-Ülemiste Canal were significantly below the relevant levels of the water bodies from which the supply for the central drinking water system is drawn.

Permanganate consumption characterizes the presence of stable organic compounds, among them natural ones, in surface water. BOD characterizes unstable organic compounds that oxidize under aerobic conditions by participation of microorganisms. Such organic compounds are found mainly in domestic sewage. Their destruction is considered to be connected with the change of oxygen balance in a water body. BOD is the principal limiting chemical indicator and is used to evaluate the self-purification processes in bodies of water.

The average value of $\mathrm{BOD}_{7}$ in summer in samples from sites I and VII was $2.1 \mathrm{mg} \mathrm{O}_{2} \mathrm{~L}^{-1}$, which is the same as the background value. This indicates that the organic compounds that fall into the river are destructed in self-purification processes. To find the ratio between easy and difficult to destruct organic compounds we used the following formula:

$$
R=\frac{\mathrm{BOD}_{7}}{\mathrm{PC}} .
$$

This formula allows us to find the proportion of natural humic compounds among all organic substances in water. The smaller the ratio, the less is the content of organic compounds originating from sewage. The data of numerous scientists show that for unpolluted water bodies the ratio $\mathrm{BOD}_{7} / \mathrm{PC}$ is below 0.4. The background value of $\mathrm{BOD}_{7} / \mathrm{PC}$ for the Pirita River was low in spring -0.08 . Similar figures were found at sites VII and VIII, thus natural organic compounds that are not biochemically destructed prevail in the water of the Pirita River. In summer the ratio was somewhat higher than in spring due to higher $\mathrm{BOD}_{7}$ values, especially in the Pirita-Ülemiste Canal.

The oxygen regime of the Pirita River was good at all studied sites (Table 1). Thus the river has the necessary conditions for efficient self-purification processes. The required minimum level of water soluble oxygen in the river water is $4 \mathrm{mg} \mathrm{L}^{-1}$. In the Pirita River the concentration of soluble oxygen fluctuated from 7.9 to $11.2 \mathrm{mg} \mathrm{L}^{-1}$. 
Our study showed that the microbiological pollution depends neither on seasons nor on the hydrological regime of the water body. We suppose that the good water quality in the Pirita River is due to intensive self-purification processes in summer and the increasing volume of water in spring. We ascertained a relationship between the most important indicator of chemical pollution $-\mathrm{BOD}_{7}-$ and the main microbiological pollution index - concentration of thermotolerant coliform bacteria, which shows the fecal character of pollution. The content of thermotolerant coliform bacteria in the water of the Pirita-Ülemiste Canal does not depend on the value of $\mathrm{BOD}_{7}$. Summarizing the previous data we can conclude that self-purification processes in the Pirita River are very intensive and sewage and waste water do not influence the microbiological quality of the water in the Pirita-Ülemiste Canal.

In the basin of the Pirita River there are no sources of oil pollution up to Vaskjala Reservoir. The content of oil products in the water at sites VII and VIII was below the level of sensitivity of the used method $\left(10 \mu \mathrm{g} \mathrm{L}^{-1}\right)$.

Table 2 presents the average values of one- and two-basic phenols in the water of the Pirita River (sites I and VII) and in the Pirita-Ülemiste Canal (site VIII). Phenols are hydroxyderivatives of aromatic hydrocarbons. Depending on the number of the hydroxy groups in their atoms the phenols are one- and two-basic. From the point of view of their influence on human health the toxicity of onebasic (volatile) phenols is higher and therefore they require more attention. Phenols are compounds of oil and oil products but they are found also in plants. Phenols are a result of the decay of organic material such as wood, peat, and humic substances. Lignin is the main compound of humic substances in wood and peat. In the decay process these substances change their structure, which depends on the natural conditions of the water body: water temperature, $\mathrm{pH}$, oxygen content, pollution of water, and others. Decay of lignin is a complicated process, as a result of which various organic compounds, among them volatile and nonvolatile phenols, are formed. Rannamäe (1978) showed that a water body may contain nonvolatile phenols that are not a result of pollution with waste water, but a result of the decay of organic material of vegetable or animal origin. Thus, the amount of total phenols may increase in an unpolluted water body, especially during a high water period, and volatile phenols may appear. The concentration of volatile phenols may reach $0.013 \mathrm{mg} \mathrm{L}^{-1}$ during the high water period.

Table 2. Seasonal changes in the average phenol content $\left(\mathrm{mg} \mathrm{L}^{-1}\right)$ in the Pirita River

\begin{tabular}{l|cc|c|c}
\hline \multirow{2}{*}{ Site } & \multicolumn{2}{|c|}{ Summer } & \multicolumn{2}{c}{ Spring } \\
\cline { 2 - 5 } & One-basic & Two-basic & One-basic & Two-basic \\
\hline I & - & - & 0.0038 & 0.0159 \\
VII & $<0.002$ & 0.023 & 0.0025 & 0.0046 \\
VIII & $<0.002$ & 0.019 & 0.0024 & 0.0049
\end{tabular}

- no data. 
It is well known that some water-soluble phenols may form in very small doses with chlorine chlorophenols that have a specific "drugstore" odour. Chlorophenols are formed with hydroxybenzene and cresols. Therefore, the permissible limit for volatile phenols in a surface water body used for drinking water supply (if chlorination is used for disinfection) is $0.001 \mathrm{mg} \mathrm{L}^{-1}$. In other water bodies the maximum permissible concentration of phenols is $0.1 \mathrm{mg} \mathrm{L}^{-1}$ with also odour being a limiting factor.

As no oil products were found in the water of the Pirita River, the phenols have to be of vegetable origin. The bottoms of the river and reservoirs are rich in organic compounds (wood, peat, water plants). Thus the presence of phenols in the river water is caused by natural processes - the decay of vegetable matter.

Anionactive detergents are widely used in Estonian households. These substances are not known as carcinogens, but their foam-generating quality makes them pollutants of water bodies as foam inhibits self-purification processes. Experiments with anionactive detergents (Veldre et al., 1977) showed that detergents inhibit the degradation of benzo(a)pyrene when their concentration in water is above their threshold limit of $0.5 \mathrm{mg} \mathrm{L}^{-1}$ (Eesti Standard, 1995). Detergents may change the organoleptic quality and chemical composition of water and the stability of saprophytic and pathogenic microorganisms and thus hinder the natural self-purification processes. In the water of the Pirita River we found $0.06 \mathrm{mg} \mathrm{L}^{-1}$ of anionactive detergents, which is the sensitivity level of the method applied.

\section{CONCLUSION}

Background values of some water quality indicators in the Pirita River (colour, content of ammonia) were often higher than in the Pirita-Ülemiste Canal. During the spring high water period the river water contained more nitrates and ammonia and the permanganate consumption had increased as compared to the summer period.

One-basic phenols in the river water were of vegetable origin and there were no chlorophenols after chlorination. Concentrations of oil products were on the level of the sensitivity of their determination method. In spring the background ratio of $\mathrm{BOD}_{7} / \mathrm{PC}$ in water was low $\left(0.08-0.09 \mathrm{mg} \mathrm{O}_{2} \mathrm{~L}^{-1}\right)$, which indicates that natural biochemically stable substances were dominating in the river. A similar $\mathrm{BOD}_{7} / \mathrm{PC}$ ratio was found in the water falling into Lake Ülemiste.

The oxygen regime in the river was favourable and ensured the required conditions for self-purification. As self-purification and dilution processes take place in the river, sewage and waste water directed into the river did not worsen the chemical and microbiological quality of the river water. The pollution indicators were on the background level in Vaskjala Reservoir.

From the point of view of environmental health the raw water of the Pirita River is safe to be directed to the Tallinn Water Treatment Plant. 


\section{REFERENCES}

Bedding, N. D., McInture, A. E., Perry, R. \& Lester, J. N. 1983. Organic contaminants. Behaviour and fate in hydrological cycle. Sci. Total Environ., 26, 255-312.

Eesti Standard EVS. Joogivesi. Üldnõuded. 663. 1995.

Rannamäe, R. 1978. Saastumatu veekogu sanitaarseisundi hindamine. Nõuk. Eesti Tervishoid, 5, 408-411.

Tammepuu, A. 1992. Kloroformi sisaldusest Tallinna joogivees. MSc thesis, University of Tartu.

Veldre, I. A., Itra, A. R. \& Paalme, L. P. 1977. An experimental study of the effect of detergents on the stability of benzo(a)pyrene. Gig. Sanit., 3, 80-90 (in Russian).

Vogt, C. \& Regli, S. 1981. Controlling trihalomethanes while attaining disinfection. J. Am. Water Works Assoc., 73, 33-40.

WHO International Agency for Research on Cancer (IARC). 1987. Monographs on the Evaluation of Carcinogenic Risk to Humans. Overall Evaluation of Carcinogenicity: An Updating of IARC Monographs Volumes 1 to 42. Supplement 7. Lyon, France.

\section{PIRITA JÕE VEE KUI TALLINNA JOOGIVEE TOORVEE KVALITEEDI HINNANG}

\section{Rein RANNAMÄE ja Ingeborg VELDRE}

Pirita jõe vee kvaliteeti hinnati organoleptiliste, keemiliste ja mikrobioloogiliste analüüside põhjal. Leiti, et mõned foonilised näitajad olid kõrgemad kui Pirita-Ülemiste kanalis. Jões olid soodsad tingimused isepuhastusprotsessideks, sest jõe hapnikurežiim oli hea. Jõevee $\mathrm{BHT}_{7} / \mathrm{PH}$ suhe oli madal, mis näitab, et vees on ülekaalus biokeemiliselt raskesti lagunevad ühendid. Jõevees leiduvad fenoolid on taimse päritoluga. Naftaprodukte ja detergente sisaldas jõevesi määramismeetodi tundlikkuse piiril. Keskkonnatervise aspektist on Pirita jõe vesi kõlblik Tallinna veevõrku suunamiseks. 